Journal of Southeast Asian

\title{
Resettlement Struggles of Burmese Refugee Students in U.S. High Schools: A Qualitative Study
}

Madhavi Tandon Dr.

University of Colorado Denver, madhavi_tandon@yahoo.com

Follow this and additional works at: https://docs.lib.purdue.edu/jsaaea

Part of the Education Commons

\section{Recommended Citation}

Tandon, Madhavi Dr. (2016) "Resettlement Struggles of Burmese Refugee Students in U.S. High Schools: A Qualitative Study," Journal of Southeast Asian American Education and Advancement: Vol. 11 : Iss. 1, Article 4.

DOI: $10.7771 / 2153-8999.1143$

Available at: https://docs.lib.purdue.edu/jsaaea/vol11/iss1/4

This document has been made available through Purdue e-Pubs, a service of the Purdue University Libraries. Please contact epubs@purdue.edu for additional information.

This is an Open Access journal. This means that it uses a funding model that does not charge readers or their institutions for access. Readers may freely read, download, copy, distribute, print, search, or link to the full texts of articles. This journal is covered under the CC BY-NC-ND license. 


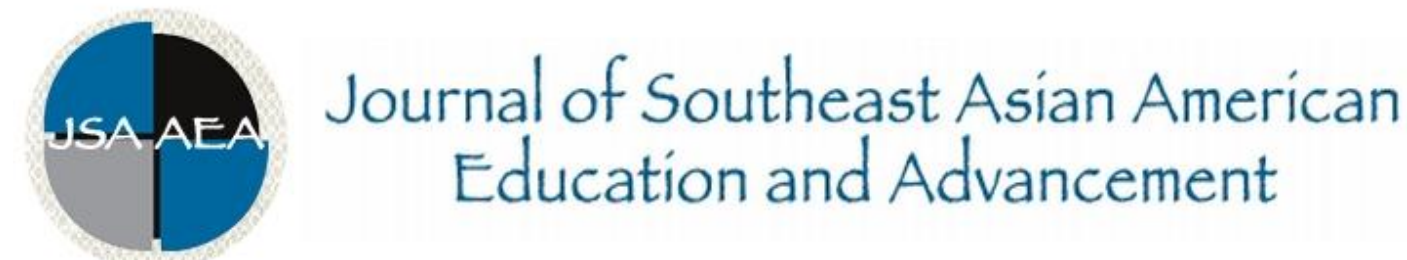

Volume 11 (2016)

WWW.JSAAEA.org

\title{
Resettlement Struggles of Burmese Refugee Students in U.S. High Schools: A Qualitative Study
}

\author{
Madhavi Tandon \\ University of Colorado Denver
}

\begin{abstract}
This article presents findings from a qualitative study that examined how five Burmese refugee students adjusted and navigated two public high schools in a Midwestern urban city in the U.S. The purpose of the study was to capture their unique histories and migration stories from which they drew strength as they resettled in the U.S. The present study focused specifically on the barriers faced by them in achieving high school graduation and impediments to higher education. Important findings included lack of navigational capital, linguicism and the intense shame of being a multilingual learner, birth order, and poor health. Other factors that negatively impacted their educational journeys included feelings of isolation and segregation from mainstream students, as well as lack of information about available resources. Theoretical frameworks of Postcolonial Theory and Critical Race Theory were used to guide the analysis of data and presentation of case studies. Data was collected using in-depth interviews, classroom observations, and home visits to facilitate a greater understanding of their education journeys.
\end{abstract}

Keywords: Refugees, Burma, Karen, school, education, resettlement, Critical Race Theory, Postcolonial Theory, forced migration

\section{Historical Background}

Burma is bordered by Bangladesh, India, China, Laos, and Thailand. It covers an area of 261,000 square miles - a land mass slightly smaller than that of Texas. The largest country in mainland Southeast Asia, Burma has fertile rice-growing areas in the center and teak-filled forests covering high mountains in the west, north, and east. (Barron et al., 2007). Burma's independence from colonial Britain in 1948 was born of bloodshed and violence between the national Burmese Army and ethnic opposition armies. Several ethnic groups living in the countryside took up arms and a long civil war ensued between the Buddhist majority and Christian minorities. Many ethnic minorities controlled their traditional areas along the Thai border until 1984 when a Burmese

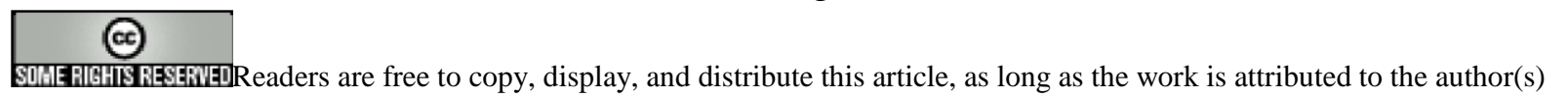
and the Journal of Southeast Asian American Education \& Advancement, it is distributed for non-commercial purposes only, and no alteration or transformation is made in the work. More details of this Creative Commons license are available at http://creativecommons.org/licenses/by-nc-nd/3.0/. All other uses must be approved by the author(s) or JSAAEA.

Journal of Southeast Asian American Education \& Advancement, Vol. 11 (2016) ISSN: 2153-8999 
offensive drove 10,000 refugees into Thailand. This event marked the beginning of a refugee outflow from Burma. (Burma Link, 2015).

The acceptance of Burmese refugees for resettlement in North America, Australia, and Europe signaled that donor countries considered it unlikely that any resolution to Burma's complex state-society and armed conflicts would be achieved soon (South, 2011). The peak year for Burmese refugees entering the U.S. was in 2009, with 18,202 arrivals (Trieu \& Vang, 2015) and the largest Burmese populations are resettled in the southern and western states of the U.S.; they are young populations, with the majority (67 percent) under forty years of age. Among the student population, Burmese students have the highest school dropout rate (44 percent) of all major Asian ethnic groups; furthermore, 33 percent of Burmese refugees live below the poverty line (Community of Contrasts, 2011), adding to the urgency of understanding the educational barriers of this group in order to inform the practices of school systems and their personnel.

\section{Significance of the Study}

"All I want to do is go back to Burma, pick up a gun and free my people." These were the words of a high school Burmese refugee student to his English language teacher. During a conversation at the same local high school where I volunteered with refugee students, the principal and the English language teacher expressed frustration regarding the lack of information and background knowledge about their refugee students and wondered how their needs could be met. The teacher added that while some of the refugee students from other countries, specifically the Bhutanese, were more motivated than average students, most of the Burmese students were 'disengaged and seemed to have checked out.' The lack of awareness and inability to relate to their Burmese students' experiences highlighted a critical gap in education research; these students required a responsive and welcoming school environment that would support their education and also provide guidance and information for mental and physical welfare. Therefore, the primary purpose of this study was to explore and understand the schooling and educational experiences of Burmese students after arriving in Liberty Town, U.S.A ${ }^{1}$. Having a better understanding of their resettlement experiences and some of the obstacles they encounter will help schools and educators respond to their needs to help enhance their learning outcomes. The following research question was formulated to guide the study: What are the educational experiences of Burmese adolescent refugee students after being resettled in Midwestern U.S.?

\section{Literature Review}

Education research on refugee students in second or third country resettlement is scant, and the number of studies that include Burmese refugee students in the U.S. is in the single digits; this study therefore responds to a gap in education literature on Burmese students. A review of education research literature on refugee students' resettlement in Western countries indicated that most studies focused on national and local policies, mental and physical health, identity formation, and perspectives of teachers, refugee parents, and families. Since this study explored barriers faced by the participants, only literature that helped understand marginalization and exclusion of refugees is included in this article. 


\section{Policy and Practice}

Schooling of resettled refugees occurs within a framework of power, racism and linguicism (Croce, 2013) where school and district policies contribute to exclusion of refugee students within the school culture (Block, Cross, Riggs \& Gibbs, 2014; Dooley, 2009; Dooley \& Thangaperumal, 2011; Gitlin, Buendía, Crosland, \& Doumbia, 2003). For refugee students, education is crucial in restoring a sense of hope and possibilities for the future (Mosselson, 2007) and schooling can provide vital opportunities to begin a new life. Paradoxically, schools are also places where refugees become highly aware of being different than other students, experience exclusion from grade level content, become marginalized and segregated as English language learners or learners with significantly interrupted schooling, and experience a disjuncture between their ideas, beliefs, values, cultures and those of the dominant group (Sinclair, 2001). In their study of school practices and policies for refugee children, Gitlin et al., (2003) found that when welcoming discourse is evident but is coupled with exclusionary practices, the resulting student success or failure is often viewed as individual rather than structural or systemic; for example, administrators at the participating middle school in their study stated that the English Language Learner program was placed in a distant wing to prevent interaction of immigrant students with U.S. students. Some other practices noted by Gitlin et al. were lack of late transportation for after-school activities, school assemblies dominated by White students, and segregated lunchroom practices facilitated by lunchroom monitors - some of the White students interviewed indicated xenophobic beliefs that refugee students would "initiate violence" (p. 116). Dooley and Thangaperumal (2011) noted similar practices that reinforced positions of marginalization and Othering of African refugee students in their study at four Australian high schools, where teachers coached the refugee students to tolerate others making fun of their accents and continually reminded them that they should feel gratitude for being in Australia.

Schooling and education are deeply political and active sites of our nation's ideological processes that are continually being restructured in a global economy geared towards capital accumulation through exploitation and dispossession (Lipman, 2013). From a national perspective, foreign policy, diplomacy, trade, and labor relations often dictate how certain refugee and immigrant groups are welcomed and accepted to the U.S. Berry's (1980) model of acculturation into Western society states that refugee and host-country attitudes toward each other's cultures determine whether certain groups of refugees will choose to integrate or assimilate. In the early 1960s, Cuban refugees were not only welcomed but received considerable financial support from the U.S. government, as it sympathized with their anticommunist cause (Pérez, 2001). In contrast, Nicaraguan refugees fleeing a similar communist regime during the Sandinista Revolution, although highly educated and professionally trained, were not granted refugee status by the U.S. government and could not create a support system (Fernández-Kelly \& Curran, 2001). Haitian refugees who arrived with low education and job-skill levels in the 1970s and 1980s suffered the most discrimination from the U.S. government of any migrant group in that period (Stepick, Stepick, Eugene, Teed, and Labissiere, 2001). Against the backdrop of the terrorist attacks in New York on September 11, 2001, refugee admissions to the U.S. dropped sharply and Muslim refugee students in schools reported being victims of verbal and physical abuse, hate crimes, teasing, and being stereotyped as terrorists (Kirova, 2001; McBrien, 2005). Thus, research indicates that policies based on international relations play an important role in how some groups of refugees are welcomed and resettled in the U.S., which directly affected the social, educational, and economic outcomes for their children. 


\section{Identity Formation}

Faced with physical growth, sexual maturation, and impending career choices, adolescents must accomplish the task of integrating their prior experiences and characteristics into a stable identity (Erikson, 1972). Furthermore, Erikson (1972) coined the phrase identity crisis to describe the temporary instability and confusion adolescents experience as they struggle with alternatives and choices. Some education research has explored the impact of adolescent identity issues for refugee students on academic outcomes, using identity formation, identity negotiation, and acculturation as theoretical lenses to analyze data. Participants in various studies reported that identity conflict was a major issue they faced during the resettlement period, and that it was accompanied by feelings of invisibility, marginalization, and alienation, which related directly to their academic outcomes (Bal, 2014; Roxas \& Roy, 2012; Dávila, 2014; Trickett \& Birman, 2005; Uptin, Wright, \& Harwood, 2014; Wallitt, 2008).

For recent refugees from non-European countries, identity seemed to be largely assigned by the host country based on prevalent majoritarian narratives, instead of being assumed or created by the student. In the U.S., most Africans were perceived to be African Americans, Asians as model minorities (Thorstensson Dávila, 2014; Wallitt, 2008) and those from Islamic cultures tended to be associated with violence and terrorism (Asali, 2003; Carter, 1999; McMurtrie et al., 2001; Wingfield \& Karaman, 2001). Identity issues, including poor self-perceptions of academic abilities (House, 2001), antisocial behavior, rejection by peers (French \& Conrad, 2001), lack of academic preparation before entering U.S. schools, lack of future goals, feeling unsafe at school, poverty, and hostile social environments (Portes \& Rumbaut, 2001) have been linked to a high dropout rate among refugees; additionally, some adolescent refugees viewed their search for identity as an obstacle to academic success (Erikson, 1968; Tollefson, 1989). One of the major findings of literature reviewed was the refugee students' frustration at being excluded, feeling invisible and being ignored academically, socially, emotionally, and ethnically in this vital developmental task of adolescence-identity formation (Chadderton \& Edmonds, 2014; Dooley, 2009; Dooley \& Thangaperumal, 2011; Harris, 2011; Hatoss, O'Neill \& Eacersall, 2012; Kanu, 2008; Lester \& Anders, 2014; MacNevin, 2012; Roxas, 2010; Roy \& Roxas, 2011, Wallitt, 2008).

\section{Theoretical Framework}

It is important to understand how, where, and why refugee students are marginalized so that educational systems can be made more equitable. To locate marginalization, refugee students' perspectives and experiences were centered in this study using two theoretical frameworks, Postcolonial Theory and Critical Race Theory (CRT).

\section{Postcolonial Theory}

Edward Said laid the foundations of Postcolonial Theory in Orientalism (1978, 1993) by explicating how the Occident or West creates the Other or Oriental. Said argued that Western ontology and epistemology were based on representing the Other as exotic, deviant, and different, and this structuring was necessary for dominating and controlling the Orient (p. 2). One of the 
modes of representing the Other is by creating what CRT calls majoritarian stories. Love (2004) defines majoritarian stories as description of events as told by members of dominant/majority groups, accompanied by the values and beliefs that justify the actions taken by dominants to ensure their dominant position. Those with racial, social, and economic privilege create beliefs about the Other by "drawing on a virtual stockroom of stereotypes developed through history and distributed through individuals, groups, and institutions such as schools and media" (Yosso, 2006, p. 9).

Most importantly, Postcolonial Theory foregrounds the notion of "U.S.-as-an-empire" (Subedi \& Daza, 2008, p. 2) and establishes the link between imperialism, capitalism and knowledge production. Imperialism is the lucrative operation that creates wealth and riches in the West through slavery, colonization and low-wage labor, without which capitalism cannot thrive (Loomba, 2005). Therefore, Postcolonial Theory provides a historical understanding of how the education of people, specifically refugees, is shaped within a power structure that is inherently unequal (Rizvi, Lingard, \& Lavia, 2006), and CRT provides the tools to pinpoint the oppression within an American context.

\section{Critical Race Theory}

CRT, as formalized in 1993 by Matsuda, Lawrence, Delgado, and Crenshaw, originated from legal studies (Ladson-Billings \& Tate, 1995). CRT centralizes race in discussions and analyses; challenges the notions of meritocracy, neutrality, ahistoricism and objectivity; emphasizes the experiential knowledge of People of Color; and supports interdisciplinarity (Matsuda, Lawrence, Delgado, \& Crenshaw, 1993). The fundamental objective of using CRT as a framework is to challenge dominant ideologies and majoritarian narratives (Love, 2004) that perpetuate inequities at the intersection of several marginalizing factors such as race, class, gender, language, ability, national origin, and heteronormativity (Yosso \& Solórzano, 2005).

CRT in education is a framework that offers perspectives and methods to identify and analyze structural and cultural aspects of education, which maintain subordinate and dominant racial positions in and out of the classroom (Crenshaw, Gotanda, Peller, \& Thomas, 1995; Matsuda, Lawrence, Delgado, \& Crenshaw, 1993; Yosso \& Solórzano, 2005). For educational scholars, CRT is a powerful tool to research and explain the large and persistent gaps in resources and achievement between White students and Students of Color by demanding a "deeper analysis of the historical and contemporary conditions that have created socioeconomic disparities" (Dixson \& Rousseau, 2006, p. 122).

This study captures the lived experiences of People of Color marginalized at the intersection of race, language and immigration, and makes their generally invisible stories, visible and heard, in order to combat the narratives told by the dominant group members (Viesca, Matias, Garrison-Wade, Tandon, \& Galindo, 2014). Counterstories, created by drawing on the experiential knowledge of marginalized groups in the form of stories, family histories, biographies, scenarios, parables, and narratives (Bell, 1987, Delgado, 1989), have the ability to expose, challenge, and critique dialogues that perpetuate racial stereotypes and show the way out of inequity and help understand how to reallocate power (DeCuir \& Dixson, 2004; Delgado, 1989). 


\section{Bringing CRT and Postcolonial}

Resistance against hegemonic and exploitative occupation of people, land and wealth took the shape of anti-colonial movements in the colonies of Asia and Africa, and as the civil rights movement in the U.S. Struggles against imperialism in the colonies and against racism in the U.S. are explicitly and universally linked in the continued war for equity and liberation. Together, CRT and Postcolonial Theory form an inseparable and powerful framework for detecting and naming marginalization specifically when it is a direct legacy of colonial policies. Historically, battling dominant ideologies and discrimination based on power and color is an ancient and ongoing struggle for People of Color around the world since the beginning of colonization, while CRT is a formalized and uniquely American culmination of the same struggle against White supremacy. When oppression occurs on U.S. soil at the intersection of race and postcolonial displacement, as in the case of Burmese refugees, using the two closely aligned theoretical frameworks strengthens the analysis of findings.

\section{Methodology}

\section{Research Design}

This qualitative research study was an exploratory multiple case study (Stake, 2006; Yin, 2003) where the principle interest was the common phenomenon among all the cases, that of being a Burmese refugee student in the U.S. between the ages of 14 and 21 . The study was bounded by one academic year (2014-2015), and was situated at two public high schools that were highly diverse in terms of their students' races and ethnicities. Liberty Town is a large urban city in a Midwestern state that is one of 12 states supported by the U.S. Office of Refugee Resettlement through the Wilson-Fish program. States in this program emphasize early employment and economic self-sufficiency (ORR, 2016) and Liberty Town welcomes approximately 2000 refugees every year with those from Burma being the second largest group (DPH, 2016). One school had approximately $70 \%$ of multilingual learners and the other had a student population that was almost $100 \%$ multilingual according to the Schools' websites. I selected the two schools because of their large refugee population and worked as a volunteer educator for one year in three classrooms. On receiving formal approval for the study from the institutional review boards of the university and school district, all refugee students from Burma were invited to participate, thus making this a purposive sample (Miles, Huberman, \& Saldaña, 2014).

Five students, as shown in Table 1 below, agreed to participate and were consented, following which I started to maintain a journal of reflections and field notes after each classroom and home visit. Data was collected over six months through weekly classroom observations, multiple semi-structured personal interviews, and home visits. All of the participants were interviewed at least two or more times for a minimum of two hours each time, and I returned for clarifications and follow-up questions as I transcribed, thus member checking throughout the process. 
Table 1

Demographic Characteristics of Participants

\begin{tabular}{|c|c|c|c|c|c|c|}
\hline Pseudonym & Gender & $\begin{array}{l}\text { Languages } \\
\text { Spoken }\end{array}$ & Religion & Prior Education & $\begin{array}{l}\text { Grade/Age on } \\
\text { arrival in } \\
\text { Liberty Town }\end{array}$ & $\begin{array}{l}\text { Grade/Age } \\
\text { at time of } \\
\text { data } \\
\text { collection }\end{array}$ \\
\hline Khin & Male & $\begin{array}{l}\text { Burmese, } \\
\text { Karen, } \\
\text { English }\end{array}$ & Christian & $\begin{array}{l}0-5 \text { years of age } \\
\text { in Burma-no } \\
\text { schooling. } \\
5-16 \text { years of age } \\
\text { in Thailand and } \\
\text { completed high } \\
\text { school. }\end{array}$ & $\begin{array}{l}\text { Arrived in } 2012 \\
\text { at age } 17 \text { and } \\
\text { enrolled in high } \\
\text { school. }\end{array}$ & $\begin{array}{l}\text { Senior (age } \\
\text { 19) in high } \\
\text { school. }\end{array}$ \\
\hline Myine & Female & $\begin{array}{l}\text { Burmese, } \\
\text { Karenni, } \\
\text { English }\end{array}$ & Christian & $\begin{array}{l}\text { In Thailand until } \\
\text { middle school }\end{array}$ & $\begin{array}{l}\text { Arrived in } 2009 \\
\text { at age } 14 . \\
\text { Entered } 11^{\text {th }} \\
\text { grade in } \\
\text { neighborhood } \\
\text { high school }\end{array}$ & $\begin{array}{l}\text { Senior (age } \\
\text { 19) in high } \\
\text { school. }\end{array}$ \\
\hline Amina & Female & $\begin{array}{l}\text { Hindi, } \\
\text { Burmese, } \\
\text { English }\end{array}$ & Muslim & $\begin{array}{l}\text { No formal } \\
\text { schooling and } \\
\text { was } \\
\text { homeschooled by } \\
\text { mother. }\end{array}$ & $\begin{array}{l}\text { Arrived in } 2012 \\
\text { at age } 20 .\end{array}$ & $\begin{array}{l}\text { Senior (age } \\
\text { 22) in high } \\
\text { school. }\end{array}$ \\
\hline Shwe & Female & $\begin{array}{l}\text { Karen, } \\
\text { Burmese, } \\
\text { Mon, English }\end{array}$ & Buddhist & $\begin{array}{l}0-8 \text { years of age } \\
\text { in Burma; some } \\
\text { homeschooling. }\end{array}$ & $\begin{array}{l}\text { Arrived in } 2007 \\
\text { at age } 9 . \\
\text { Entered } 3^{\text {rd }} \\
\text { grade in } \\
\text { neighborhood } \\
\text { elementary } \\
\text { school. }\end{array}$ & $\begin{array}{l}\text { Sophomore } \\
\text { (age 16) in } \\
\text { high school. }\end{array}$ \\
\hline Htway & Female & $\begin{array}{l}\text { Poe Karen, } \\
\text { Karen, } \\
\text { Burmese, } \\
\text { English }\end{array}$ & Buddhist & $\begin{array}{l}\text { In Thailand until } \\
3^{\text {rd }} \text { grade. }\end{array}$ & $\begin{array}{l}\text { Entered } 5^{\text {th }} \\
\text { grade in } \\
\text { neighborhood } \\
\text { elementary } \\
\text { school. }\end{array}$ & $\begin{array}{l}\text { Sophomore } \\
\text { (age 16) in } \\
\text { high school. }\end{array}$ \\
\hline
\end{tabular}

Data were analyzed firstly as individual and single cases using constant comparison analysis (Glaser \& Strauss, 1967) to generate broad themes, classical content analysis (Berelson, 1952) to determine the frequency of codes generated and to learn which codes occurred more or less frequently in the data, and finally, using versus coding (Saldaña, 2013). Saldaña (2013) recommended versus coding for research that used a critical perspective, as was done in this study. The versus coding technique in each case was used to understand the tension that existed in participants' lives, as they were torn between commitments to school, college, family, work, and community.

In a second step, cross-case analysis of the five single cases was carried out using a combination of variable and case oriented approaches that facilitated the comparison of commonalities and differences in the events, activities, and processes that were the units of 
analyses in single case studies (Khan \& VanWynsberghe, 2008; Miles, Huberman, \& Saldaña, 2014). In variable-oriented research, variables and their interrelationships with each other took center stage and less case-to-case comparison was done (Miles, Huberman, \& Saldaña, 2014) while in a case-oriented approach, the case was considered as a whole entity (Ragin, 1997). Configurations, associations, causes and effects within the case were studied first, and then a comparative analysis of all the cases in the study was carried out (Miles, Huberman, \& Saldaña, 2014).

\section{Limitation of the Study}

The findings of this study are important given the continual influx of refugees from various Asian, Middle Eastern and African countries into the U.S. However, some limitations should be considered in interpreting the findings. Firstly, as the study was non-experimental, no causal connections can be drawn and secondly, the nonrandom, small, and limited sample of participants implies that the findings of this study cannot be generalized or applied to younger or older refugee students from other countries. Additionally, the interviews were conducted at a single point in time, from June to August 2014, instead of longitudinally, which would have provided richer information on how the meaning of education and success evolved as participants graduated high school and went on to lead adult lives. Moreover, only students who volunteered were participants in the study, hence it will be unknown if and how findings would have been different if nonvolunteers would have been interviewed.

It would be remiss to ignore my role and interest in designing the study. A researcher cannot be separated from her epistemology or her ways of understanding the world, and as such, I need to explicitly clarify mine.

\section{Researcher Role}

The motivation for the study is rooted in my identity and experiences as a South Asian immigrant educator. In the quest for assimilation and acceptance, immigrants to the West are continually subjected to social, educational and economic pressures to increase their fluency in English at the cost of their native languages. Moreover, the act of mastering English leads to internalized beliefs that White native speakers of English are inherently superior to non-native, Brown, and accented speakers of English. Being multilingual like all the participants, and specifically fluent in Hindi, was a crucial factor in building relationships with some of the participants and their families. Burma and India are neighboring countries and have been connected through centuries by religions, trade, languages and politics. Hindi and other Indian movies are popular in Burma and as a result many Burmese people are familiar with the Hindi language. Relieved to hear Hindi, family members of some participants enthusiastically joined the conversation and volunteered information that may not have otherwise been offered. Furthermore, phenotypically, I resembled some of the participants and their families and also dressed like them in traditional ethnic clothes such as salwars and kurtas. These similarities were an important factor in building trust and being perceived as an insider in direct opposition to all the White persons in authority that they encountered. 


\section{Findings and Analysis}

This section will first introduce each participant as a single case study with some analysis of their personal contexts and later, findings and analyses across the five cases will be presented under three themes: lack of navigational capital, linguicism and shaming, and intersectionality.

\section{Single Case Vignettes and Analysis}

The purpose of this study was not to present any one single case as exemplary or critical but to discover themes that were seen across cases. However, each single case was unique and the vignettes presented below ensured that unusual and singular features of each participant's story are captured and documented.

Khin. Khin was a quiet Burmese male who preferred to listen to others rather than express his opinions. Khin offered minimal information about his place of birth or his years in Thailand as a refugee. I learned that he went to a school run by Catholic charities in the Thai refugee camps and was a devout Christian. He lived in Liberty Town with his parents and three siblings. Khin had graduated from high school in Thailand and was enrolled as a senior at the time of data collection. He stated that he found school to be extremely boring, but persisted nevertheless as education was important for his future success.

Khin lived with chronic back pain from an injury he received in Thailand, and that pain prevented him from attending school regularly. Khin mentioned a few times that he was interested in becoming a nurse or pursuing a profession that would help his ethnic Karen community, specifically to tackle the problem of obesity. Although he had articulated his plans clearly, Khin had not explored any career options or institutions that would help him achieve his goals. Khin's quiet determination and confidence was promising, but he hesitated to reach out to counselors and teachers due to lack of English language fluency and lack of confidence in approaching people in authority.

Amina. Amina was a young lady with a lot of self-advocacy whose family was the first Burmese Rohingya Muslim family to resettle in Liberty Town. From the first visit to her home for an interview, Amina's family welcomed me as one of their own and we shared a kinship because of being able to converse in Hindi. Prior to coming to Liberty Town, Amina had lived in Malaysia for 20 years as an illegal immigrant, where she was house bound and rarely ventured outside for fear of being kidnapped and trafficked by smugglers. Amina had never attended school and had been tutored at home by her mother in English, Hindi, and mathematics. Her entire family supported Amina's schooling in the U.S. and shared her determination to go to college. Amina wore a traditional headscarf and had faced several instances of racism in various public spaces in Liberty Town, such as the metro and bus stations, and she feared White people. The first in her family to go high school, Amina wished to become a doctor, and we spent several hours on the internet exploring pathways to health careers. An extremely cheerful person and a dedicated student, Amina was eager for any opportunities to further her education and was working as a student assistant for two of her high school teachers.

Amina's parents were leaders in the small Rohingya community of Liberty Town and Amina was actively involved in helping newly arrived refugees by accompanying them to various 
appointments such as schools, hospitals, and social services. Frequent interactions with people outside her community had gradually instilled in her feelings of confidence and self-efficacy, and she used every opportunity to practice English. Amina was relieved that her parents were not forcing her to get married and their support was crucial to her education.

Myine. Myine was a young and fashion-conscious Burmese Christian lady who had grown up in a Thai refugee camp after fleeing Burma with her family when she was two years old. Myine arrived in Liberty Town as a high school freshman but was several years behind in literacy and numeric skills. The third of eight children and the oldest child living at home, Myine lived with her parents and five younger siblings in a small two-bedroom rented apartment. Myine's father was disabled and rarely left his room, while her mother worked long hours at a local meat packing plant and was the only family member who earned money. Myine was the primary caregiver for her father and siblings and sought to balance these duties with her school commitments.

Myine was the most impacted of all participants in terms of education as she had been living with an undiagnosed learning disability since 12 years of age. The inability to comprehend and cope with school work had led to frustration, depression, and low self-esteem. Myine also harbored feelings of anger towards the repressive regime in Burma and often mentioned that she would join the revolutionary army if she found a way to do so, especially since she felt like an outsider in Liberty Town, which, according to her, belonged to Mexicans and not Asians. Feeling alone and isolated, Myine bravely tried to manage her education and family's needs. One of Myine's strongest assets was her determination and lack of fear. She stated that she was not scared of anything or anyone and was ready to face any obstacles that may arise in her life.

Shwe. Shwe had finished her sophomore year at the time of our interview and was looking forward to her summer vacation. Of Mon ethnicity, Shwe was deeply involved with the Buddhist temple activities of Liberty Town where she lived with her parents and younger brother in a small single-family home near her school. Shwe had fled Burma with her family when she was six years old and had spent a year in Thailand before moving to the U.S. Fluent in English and with a GPA of 4.4, Shwe was a gifted student who dreamed of becoming a doctor and worried that she was not working hard enough to make her dream come true. Shwe's parents worked in a factory that assembled doors and she was the primary caregiver for her brother as they would leave home before Shwe went to school and would come back in the evening. Shwe ensured that her brother was fed and that he completed his homework while she did her own.

Shwe was enrolled in traditional Mon dancing lessons and traveled across the state with her troupe to perform. As compared to some other participants in the study, Shwe's family was financially more secure, and she was not required to work outside the house. Driven by a desire to make her parents happy, Shwe was excited about her future, but also anxious that her parents' mistrust of schooling would deprive her of academic opportunities.

Htway. Born in a refugee camp in Thailand, Htway came to Liberty Town in fifth grade, speaking only Poe Karen and Burmese. At the time of our interview she had finished her high school sophomore year and was preparing to travel out of state for several weeks over summer. Htway lived in Liberty Town with her parents and three of her seven siblings. Some of her siblings were in another state while some were still in Thailand. Htway was the youngest of eight children and was actively involved in after school activities. At the time of our interview, Htway had finished a two week retreat as a monk and had spent that time living and meditating at the local 
Buddhist temple. Htway also played volleyball for her school team and worked as an assistant manager for a junior team, which required her to stay back after school every day until $7 \mathrm{pm}$ for practices. Her family supported her extracurricular activities and in turn Htway taught volleyball to young Burmese refugees at a youth group.

Htway and her older sister were the first in their family to be enrolled in schools and with no one to guide the girls' education, Htway shared that it had been difficult and frustrating for her to navigate the college admission process. Htway stated that going to college would be symbolic and she wanted to do her best and make her parents proud.

\section{Cross-Case Analysis}

Education and schooling after arrival in the U.S. was shaped not only by the participants' previous experiences but also by a range of factors that were related to schools and classroom learning. Data showed that all the participants encountered three common obstacles, which are lack of navigational capital, linguicism and being segregated as English language learners, and intersectionality of multiple marginalizing factors (Crenshaw, 1991) such as being first born and suffering from poor health.

Lack of Navigational Capital. Institutional agents such as school counselors, advisors, teachers, and administrators are of significant importance in the lives of high school students, as they hold vital information related to college access, scholarships, and grants (Oropeza, Varghese, \& Kanno, 2010). Some of this information is built and shared by families and communities over multiple generations, which Yosso (2005), terms as navigational capital; however, in the case of the five participants, six of ten birth parents, had never attended school in their home countries, as shown below in Table 2, with the highest level of educational attainment being elementary school in Burma. Thus the navigational capital shared by parents was limited to their personal educational experiences in Burma, which were starkly different than those of their children after resettlement in Liberty Town.

Table 2

Education history of participants' parents

\begin{tabular}{llll}
\hline Participant & $\begin{array}{l}\text { Years of schooling received by } \\
\text { Mother in Burma }\end{array}$ & $\begin{array}{l}\text { Years of schooling received by } \\
\text { Father in Burma }\end{array}$ \\
\hline Khin & $1-5$ & $1-5$ & \\
Myine & 0 & 0 & \\
Amina & $1-5$ & 0 & \\
Shwe & 0 & 0 & \\
Htway & 1 & 0 & \\
\hline
\end{tabular}

As most of the Burmese parents lacked formal schooling, it had direct consequences for the participants in terms of accessing educational services and opportunities in the U.S., a culture and system far removed and distant from Burma. The skills and systems, mainly related to subsistence agriculture and animal husbandry, that they knew were inadequate to negotiate and navigate the bureaucracy of the U.S. education system, and parents felt intimidated by the schools and their staff. Data clearly indicated that participants' parents were not likely to negotiate and advocate with the school districts for focused educational interventions and services that they did not know existed. At several homes during visits for research purposes, my help was sought in 
filling out paperwork and in translating and interpreting official documents. For example, Myine's mother asked me to fill out applications for food stamps, Amina's parents asked me to complete public school open enrollment applications for Amina's younger sister, Shwe asked me to write formal emails on her behalf to universities seeking enrollment information, and Htway's sister asked for help in locating GED classes. This was a clear indication that although parents and families were deeply supportive of their children's education, lack of formal schooling and knowledge of U.S. systems intensified their struggles around navigating schooling resources and supports that were available in U.S. public schools. The types of parental involvement valued in U.S. schools - communicating, volunteering at school, and learning at home (Huntsinger, \& Jose, 2009) seemed inaccessible to most parents of participants in this study.

Additionally, most of the parents were wary of Western school systems that were unfamiliar to them and preferred that participants had minimal contact with White peers and other school staff. Parents who may have witnessed indoctrination and deliberate inculcation at the hands of repressive colonial and domestic regimes in Burma wanted to limit their children's exposure to authority and Western influences. Amina shared that she and her younger sister did not have any friends at school because her parents had warned them about being 'exploited' by other students. Myine said that she chose not to socialize with any school friends and staff as nobody understood her. Shwe, gifted and ambitious, often expressed her frustration with her parents' mistrust of U.S. schools as she was the most Americanized participant and struggled to balance the American and Mon cultural influences. Shwe stated that she tried not to mix her two identities and defined herself as "being perfectly American at school and completely Mon at home." Shwe's frustration with her parents indicated that she had internalized the Western model of parental involvement in schools as crucial to academic success and perceived her parents' wariness of U.S. schools to be in direct conflict with her goals leading to severe academic losses for her, and said:

Since my parents are not involved in my school I don't know how to explain to them... because the things are different here, the schools ya. Ya, I am worried, I don't know because I'm late. So I am worried.

On the other hand, Htway explained that she and Aung, her older sister, navigated their own education, and her parents only wished for her life to be "very different" from theirs and they would be "really upset" (Interview, 2014) if she did not go to college, indicating their support. However, Amina's mother had some formal schooling and understood what type of knowledge was valued in U.S. schools. She used her skills to seek information from volunteers and case workers and succeeded in enrolling Amina for a summer college class to gain experience. Amina's mother also reached out to non-profit and charity organizations and collected information on school choice and open enrollment. It was apparent that Amina's mother's prior experience with school systems in Pakistan, Burma, and Malaysia was extremely helpful in furthering Amina's access to academic supports and opportunities. Most of the other parents did not have access to the social, educational, economic, and navigational capital that would have helped advocate for their children at the school or district level.

Linguicism and Shaming. At the time of data collection, English language skills among the participants varied from the highest, Level 6 or Bridging, to Level 1 or Entering as described by the WIDA Can Do Descriptors used in the schools (WIDA, 2014). Shwe had been exited from 
special English language instruction while Htway was in the highest class for English language learners. The other three participants ranged from Level 1, beginning or entry level skills, to Level 5, some metacognitive and negotiation of meaning skills (WIDA, 2014).

From the participants' perspectives, learning English in their new country seemed to be the single most difficult hurdle they faced. The notion that if English was conquered then every other hurdle would disappear was a recurring theme in their narratives. Some wondered if their eventual career choices would be determined by their mastery of academic English. Even Htway, who was fully proficient in English believed, "It [career] depends on if I know a lot of English, then it will be easy to find a career" (Interview, 2014). While Myine summed up her future as "No no, no college, I'm not good at English so no college. Sometimes I am thinking that is only the possible job-working in meat packing like my mother" (Interview, 2014).

Some participants had analyzed their own strengths and weaknesses in learning English and knew precisely what supports were needed to increase their competency and fluency but did not want to ask for more resources at school. Myine knew she needed help in reading and comprehension, Khin in oral fluency, and Amina in grammar. However, all participants stated that they were too shameful to ask for more or targeted help. Shame originated from the fact that they were almost adults and that in spite of learning the language for several months or years they were unable to speak it fluently. They stated that these feelings of shame prevented them from reaching out to teachers, peers, and more proficient younger siblings for help for fear of being mocked. Four of the five participants in this study felt that they were reduced to English language beings and thought of themselves as more or less competent and worthy based on their fluency in English. Even though some were strong in mathematics, science, and other content areas, it always came down to their level of English. Feelings of self-worth and ability to attain the American dream were judged through a simple lens - that of English language proficiency. Language was also the biggest source of anxiety in the context of higher education and success, as shown below in Figure 1. As Htway shared, "I get really nervous to talk to someone [in English] if I don't really know them but I also worry if I gonna say right or say wrong like that" (Interview, 2014).

Some of the emotions and thoughts associated with being multilingual learners in a monolingual society as expressed by the participants are mapped in Figure 1 below.

Being multilingual in the $21^{\text {st }}$ century is a globally valued asset, as is the ability to adapt to new countries and systems; however, the participants' lack of fluency in English led them to internalize feelings of inferiority and imbibe the message that English was the gatekeeper to success. All participants noted their segregation from one another and from mainstream students based on fluency in English. Critically speaking, the rhetoric that academic English was a prerequisite for higher education in the U.S. had been accepted unquestioningly by the participants, even those who had arrived recently. This acceptance was indicative of the way schools framed the notion that higher education in the U.S. was accessible only through English and only to those students with almost native fluency in the language. The monolingual education system had been successful in achieving its purpose of creating lowered expectations and aspirations for refugee students by devaluing their multilingual backgrounds and abilities to learn in several languages and steering them towards a much needed minimum wage workforce (Galindo, 2011; Mitchell, 2012). 


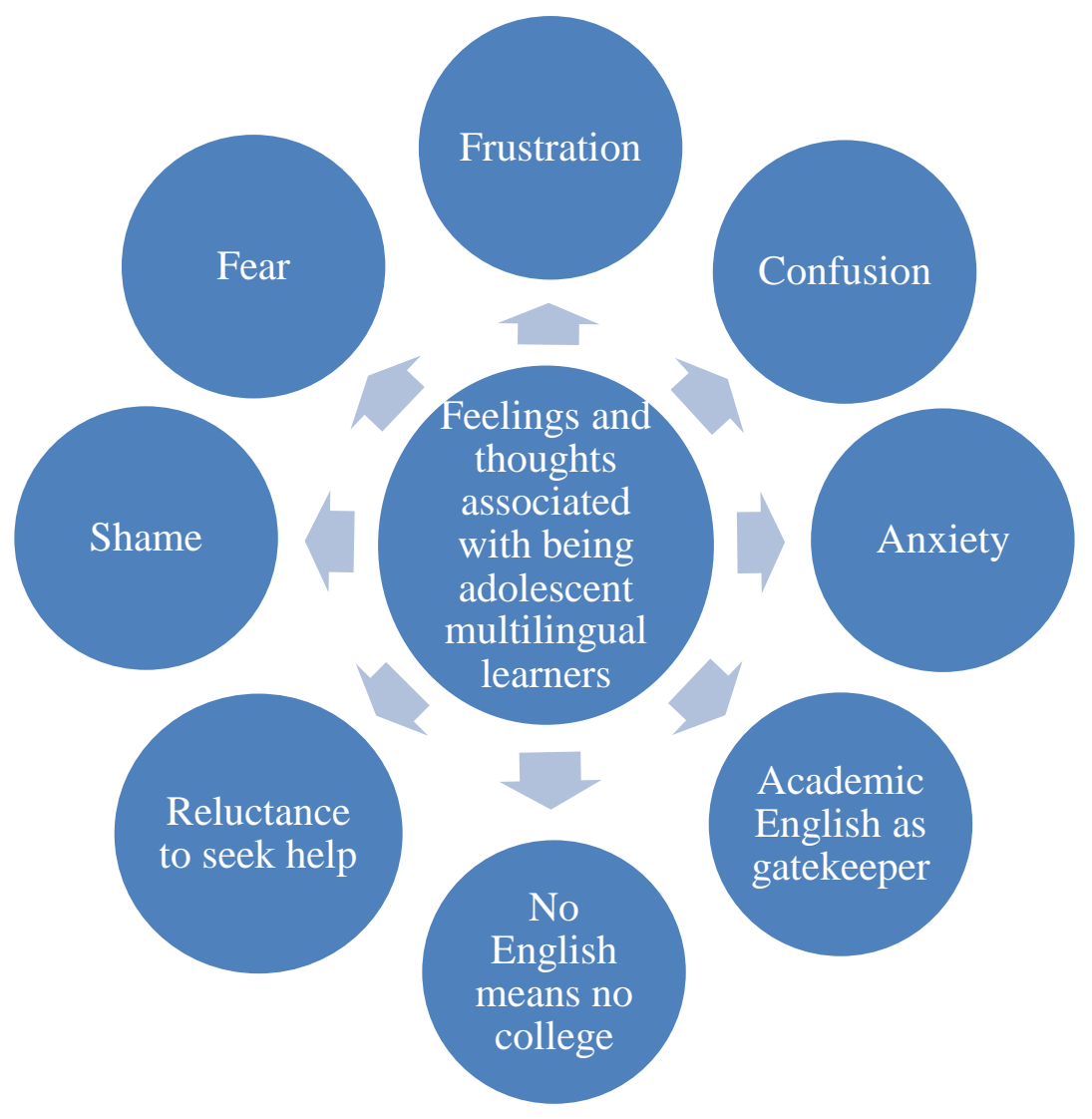

Figure 1. Feelings and thoughts associated with being adolescent multilingual learners

\section{Intersectionality of Multiple Marginalizing Factors}

In addition to being the first in their families to attend high school and trying to compensate for the lack of their English language fluency, some of the participants' educational journeys were rendered more complex by an intersectionality of factors such as being first born or having health traumas. Crenshaw (1991) has defined intersectionality as various ways in which race interacts with other factors such as gender, ability, and class to shape the experiences of People of Color.

Birth order. Whether a participant was born first, second or was the youngest in the family had a long lasting and considerable impact on his or her schooling. On arrival in Liberty Town, all participants were enrolled in schools that seemed appropriate to their age; however, enrollment decisions were made either by the state caseworker assigned to the family or by persons working with volunteer and charitable nonprofit organizations. The participants and their families, most of whom had never been inside a school in their lives, were not aware of the enormity of this decision and how it would shape their careers. The younger participants had more time to assimilate and were enrolled in schools that had more native English speakers, while the older participants were tracked into alternative and vocational schools where the majority of students were multilingual. 
Shwe and Htway, who came to the U.S. in elementary school years, had a longer and gentler settling-in period, with natural transitions from elementary to middle and high school, as compared to Khin, Myine and Amina, who were steered to an "alternative school focused on retrieving students 17 to 20 who left high school before earning a diploma" (Public school website, 2015). The education system and resettlement agencies placed them in an environment where they were taught only English, thus sending a message that it was the only subject they were capable or worthy of learning or that it was the only one needed to learn to create their place in the labor force. Tracking refugees into alternative or vocational schools also served the purpose of upholding White privilege and creating a low skilled labor force that could bus tables, run industrial-sized washing machines or load and unload trucks all day long (Chadderton \& Edmonds, 2014). Fortunately, Khin, Myine, and Amina realized the alternative school was not a good option as, they taught "no science, no math, very boring, only English for hours and hours" (Amina, Interview, 2014) and by asking other refugees in their neighborhoods for information enrolled themselves at one of the high schools in this study; however, many of their peers were unable to do so.

The birth order of two female participants, Myine and Shwe, placed them in the role of primary caregivers for their families leading their days to be intricately balanced between responsibilities at home and at school. Myine was the oldest child living at home and Shwe was the first born. Myine's family consisted of her parents and five younger siblings while Shwe lived with her parents and a younger brother. Myine was responsible for all family members' well-being and said, "I cook for everyone every day, I clean, wash the clothes" (Interview, 2014). In some ways Myine felt that she was obligated to look after her siblings due to her parents' advanced age and felt that she must sacrifice her own life in order to look after her family:

I don't think I will go to college. I will probably be working. I will work. My mother works, she is getting quite old and seeing her work makes my heart sad. She should not be working at this age. I will work and whatever I earn I will use it to pay for my siblings' college. (Interview, 2014)

Although Shwe had only one younger brother, she felt responsible for his well-being as her parents worked long hours and did not really understand the school systems in the U.S. Shwe's parents would leave early in the morning to work at a factory over an hour's drive from Liberty Town and would call her from there to wake her up for school. Shwe was then responsible for getting herself and her brother ready, fed, and to school on time. After coming home from school, Shwe cleaned and cooked for the entire family before doing her homework and then in turn helped her brother with his school work. Besides taking care of her own and her brother's needs, Shwe was also a fierce advocate for her younger brother and was preparing him for college even though he was in elementary school at the time of data collection. Shwe practiced speaking English with him and exposed him to English language programming on television. With big dreams of becoming a doctor, Shwe was simultaneously grooming her brother to become successful, "I'm helping him get there, I'm really hoping he'll get there. I think he's too little to understand that if you don't go to college you can't live that well' (Interview, 2014).

Khin, Htway, and Amina had older siblings who worked several minimum wage jobs and had not gone to any school or college. Khin had one older brother, Htway was the youngest of eight siblings, while Amina was the second youngest of five. Having one or more older siblings to bear the burden of making ends meet or taking care of the social and emotional well-being of their 
families freed up the younger siblings to somewhat enjoy their teenage years and focus more on school.

Amina had three older siblings who worked two or more jobs each as dishwashers or in the laundry department of local hotels. All three of them encouraged her to be the first in the family to graduate from high school was told not to work and to save her energy for school; moreover, she had a lot of support from her parents and older siblings to pursue any career she wanted and was not being coerced into early marriage as was the norm in their Rohingya Muslim community.

Similarly, Htway, youngest of eight siblings, did not have many responsibilities at home, she stated "if there is something we have to do, go to an office somewhere, then my sister goes, because I am sometimes very busy doing dancing, things with the community" (Interview, 2014). Htway had the time and energy to pursue her passion for traditional Burmese dancing and spent many weekends traveling with her troupe. Htway was also a member of her school's volleyball team and stayed back every evening to practice. When specifically asked about chores at home Htway said, "not in the school day. On holidays or sometimes; we don't celebrate a lot in our family, sometime my mom she wakes up early and does all the work. I don't have to do" (Interview, 2014). Being the youngest, Htway had the freedom to divide her time between school, volleyball, and dancing.

The older participants, Myine and Shwe, always seemed to be running against time in trying to get school work done and not be tardy, earn money for the family, and help with household chores during the time in between. A critical analysis shows that the time, energy, resources, and money that could be devoted to education were competing with other needs. The older siblings, overwhelmed by familial and financial responsibilities, had little energy to reflect upon how they were shepherded into a lifestyle that perpetrated capitalist production of inequalities. The older participants were worthy to the U.S. only as low wage labor who would know enough English to carry out their jobs but not enough to access higher education.

Health. In addition to school, family, and work, two participants in the study reported that they had to deal with serious health issues at home, which in turn shaped their experiences at school. Health competed for their time and sometimes kept them out of the classroom and at hospitals and doctors' offices.

Myine and Khin both suffered from personal health problems that interfered with their school. Khin stated that he was living with back pain and had sought some treatment for it, but it continued to hurt, while Myine stated that she had a "bad brain" (Interview, 2014). She described an episode of blacking out in a forest in Thailand while chopping firewood when she was approximately 12 years old. Since the blackout, she stated that her brain had been severely affected, "I don't understand very well, the other students in my class, they understand more than me. Even in Thailand and here" (Interview, 2014). During classroom observations, I noted that Myine struggled with reading and writing and needed to be diagnosed for learning disabilities. However, her teacher said that the school was not equipped to test Myine because of a language barrier (Field Notes, 2014). None of the schools that Myine attended in Liberty Town had tested her for any learning issues and slowly Myine had grown to resent school. She wanted to go to college but doubted that she was capable. Myine's bad brain and Khin's bad back were often reasons they did not complete their assignments, did not participate in classroom activities, or were absent from school. Furthermore, Myine was the primary caregiver for her disabled father, who was bedridden. Due to lack of information about disability rights for students, Myine and Khin's families did not know that they could have pressed the schools for diagnostic testing or requested special 
accommodation plans. This would have set them both on academic trajectories that supported their schooling instead of encouraging the possibilities of dropping out or failing high school.

Education and refugee research literature states that many refugees tend to have mental and physical health-related issues due to the years spent in camps and transition (Hones \& Cha, 1999; Montgomery, 2011; Sinclair, 2001; Tollefson, 1989). Making the situation even more complicated was the inability or unwillingness of schools to diagnose and support learning disabilities and challenges of refugee students (Hurley et al., 2014). Myine's teacher shared that "we do not know how to test Myine, there is something definitely going on but we don't know how to help" (Field Notes, 2014). The school would not have been able to make this excuse had Myine and her family been aware of their rights to accommodate learning and could have forced the school to provide appropriate services.

Inability to cope with their own illness pushed some of the participants into thinking that they were incapable and unable to succeed, or that they had to limit their ambitions. If we, that is, developed Western nations, promise refuge to displaced migrants without adequate supports for health and education, we are continuing their trauma while exploiting their labor, which is a form of continued colonization. Participants in this study had little or no power to advocate for their rights, and by not offering intervention or treatment, schools continued to silence their needs and voices.

\section{Discussion and Implications}

The flow of refugees into the U.S. and Europe is ever-increasing, and findings from this study have implications for all stakeholders in the education system. Equitable education has never been the norm and will not be handed on a platter to refugees unless inequities are named and conscious efforts to redress them are made as outlined below. Improving the flow of information to and from schools to refugee families, ending linguistic isolation, and creating hybridized educational spaces where refugees can contribute and succeed are some changes that can be effectuated to improve outcomes and move refugee students and families away from a lifetime of poverty.

\section{Information Flow}

Increasing the flow of information to parents about school structures such as open enrollment, school choice, advanced classes, IEPs, and learning disability assistance, either through community organizations or activists, will help build relationships and foster trust between schools, students, and parents. Encouraging parents to accompany their children to some academic activities, or opening up the schools for parallel literacy or social activities for parents and ethnic communities would allow families to experience positive interactions with school authorities. Reassuring parents and engaging with them to learn about their fears around education and schooling would be one of the first steps that could be taken by schools.

Taking into account the lack of parental experiences with formal schooling, decades spent in refugee camps, persecution, and violence witnessed or suffered, it is not unusual for parents to want to protect their children from outside influences. However, when parents limited the contact their children had with schools, they also inadvertently deprived them of much-needed tutoring, academic guidance, and opportunities for social interaction with native English speakers. 
Educators and schools should bring these resources to spaces that are located within the communities and outside the school premises while simultaneously increasing transparency and access to schools. Improving the flow of information from schools to students and from students to schools would provide crucial background information to educators, as seen in this study.

\section{Isolation, Interaction and Facilitation}

As facilitators of opportunities, schools that have or anticipate a sizeable number of high school refugee students can work together with the diversity and inclusion departments of local colleges and universities. Refugee students are not usually included in diversity initiatives as a distinct minority group, and classification of refugees as either Black or Asian is misleading and detrimental. The Burmese refugees in this study did not fit the currently prevalent model minority racial stereotype unlike other Asian Americans groups who have well-established social and academic networks.

Large amount of research and empirical studies have demonstrated that English language acquisition for second language learners needs native speakers as peer partners to practice and learn different aspects of the language (de Jong \& Harper, 1995). Isolation of multilingual learners from native speakers of English until they reach a certain acceptable standard of linguistic fluency deemed fit by the school or district is colonial, oppressive, and inequitable. Learning not only a language but a new way of being and knowing in isolation can only have limited positive outcomes. Newcomers should have equitable time in mainstream classrooms with native peers during a school day to learn collaboratively, from and with each other.

\section{Hybridization of Educational Spaces}

When a group of non-traditional students encounters a traditional system of education that has no hybrid spaces, they will either fail or leave the system. Bhabha $(1994 ; 1996)$ defined the concept of hybridity in postcolonial studies as cultural mixing between the colonizer and the colonized, where both sides are changed and influenced by each other. Hybridity is not a simple mixing of two cultures to produce a third, but is a space that is continually negotiated by those with power and without. Bhabha argues that all social collectives, nations, cultures and small ethnic groups are continuously chafing against each other and jostling for space; a notion that Anzaldúa (1987) applied to the borderlands between Mexico and the U.S. and described as "where the Third World grates against the First and bleeds" (p. 25).

The image of a successful student as an assimilated one who is fluent in American English, is rooted in coloniality and White supremacy. In a hybrid space, English should be viewed as a language that belongs to several peoples and cultures, with different purposes ranging from an indicator of complete assimilation to a tool that allows access to certain types of knowledge. With newer, older and more globalized student profiles entering our schools, policies and pedagogies need to be respectful and should also be able to address the economic realities of living in a Third World inside the First. 


\section{Conclusion}

A Third World within the First reinforces and replicates historical patterns of dominance, power, control, and influence, where economic and social mobility is available but concentrated within the confines of White middle and upper class lives, while those outside are pushed even further into the margins of society, into inner cities where low-wage labor, inadequate housing, and poor schools are the norm. These clusters of human settlements should be viewed by researchers as pockets of Third World whose presence are indicators of education apartheid (Kozol, 2008) among other inequities. The presence of the Third World within minutes of our daily lives and commutes becomes normalized through exclusion-most Americans do not have to make contact or enter this Third World, and can spend their lives without encountering gross disparities unless they choose to do so. If we assume that the larger project of education is to create knowledgeable and democratic citizens, centering the participants' stories becomes essential so that pedagogies and curricula that build on their strengths, resilience and hard work can be created. Greater efforts are required by those in power to change school policies that can specifically address adolescent refugee students and create explicit programs to encourage their equitable and active participation.

\section{Endnotes}

1. Names of cities, refugee camps, schools, and persons have been changed to protect the identities of the participants; only names of countries have been retained to facilitate understanding of geographical migrations.

\section{References}

Anzaldúa, G. (1987). Borderlands/la frontera: The new mestiza. San Francisco, CA: Spinster/Aunt Lute Press.

Asali, Z. (2003, March). Of liberty, security, and the human spirit. Paper presented at the Confronting Racial Profiling in the 21st Century: New Challenges and Implications for Racial Justice conference, Northeastern University, Boston, MA.

Bal, A. (2014). Becoming in/competent learners in the United States: Refugee students' academic identities in the figured world of difference. International Multilingual Research Journal, 8(4), 271-290.

Barron, S., Okell, J., Yin, S. M., VanBik, K., Swain, A. Larkin, E., Allott, A. J., \& Ewers, K. (2007). Refugees from Burma: Their backgrounds and refugee experiences. Washington, DC: Center for Applied Linguistics.

Bell, D. (1987). And we are not saved: The elusive quest for racial justice. New York, NY: Basic Books.

Berelson, B. (1952). Content analysis in communicative research. New York, NY: Free Press.

Berry, J. W. (1980). Acculturation as varieties of adaptation. In A. M. Padilla (Ed.), Acculturation: Theory, models and some new findings. Boulder, $\mathrm{CO}$ : Westview. 
Bhabha, H. (1994) Location of cultures. London, UK: Routledge.

Bhabha, H. K. (1996). Culture's in-between. In S. Hall \& P. Du Gay (Eds.), Questions of cultural identity. (pp. 53-60). New York, NY: Sage

Block, K., Cross, S., Riggs, E., \& Gibbs, L. (2014). Supporting schools to create an inclusive environment for refugee students. International Journal of Inclusive Education, 18(12), $1337-1355$.

Burma Link, (2015). History Since Colonisation. Retrieved from http://www.burmalink.org/background/burma/history-since-colonisation/

Carter, R. B., \& Hindi, A. E. E. (1999). Counseling Muslim children in school settings. Professional School Counseling, 2(3), 183.

Chadderton, C., \& Edmonds, C. (2014). Refugees and access to vocational education and training across Europe: A case of protection of white privilege. Journal of Vocational Education \& Training, 67(2), 136-152.

Asian Pacific American Legal Center \& Asian American Justice Center. (2011). A Community of Contrasts: Asian Americans in the United States. Washington, DC: Author. Retrieved from http://www.advancingjustice.org/publication/community-contrasts-asian-americans-us2011

Crenshaw, K. (1991). Mapping the margins: Intersectionality, identity politics, and violence against women of color. Stanford Law Review, 43(6), 1241-1299.

Crenshaw, K., Gotanda, N., \& Peller, G. T. K. (Eds.). (1995). Critical race theory: The key writings that formed the movement. New York, NY: The New Press.

Croce, K. A. (2013). Assessment of Burmese refugee students' meaning making of scientific informational texts. Journal of Early Childhood Literacy, 14(3), 389-424. Doi: 1468798413508423.

Dávila, L. T. (2014). Performing allegiance: An adolescent refugee's construction of patriotism in JROCT. Educational Studies, 50(5), 447-463.

DeCuir, J. T., \& Dixson, A. D. (2004). " So when it comes out, they aren't that surprised that it is there": Using Critical Race Theory as a tool of analysis of race and racism in education. Educational Researcher, 33(5), 26-31.

De Jong, E. J., \& Harper, C. A. (2005). Preparing mainstream teachers for English-language learners: Is being a good teacher good enough?. Teacher Education Quarterly, 32(2), 101124.

Delgado, R. (1989). Storytelling for oppositionists and others: A plea for narrative. Michigan Law Review, 87(8), 2411-2441.

Colorado Department of Public Health and Environment, (2016). Refugee surveillance demographic data on refugees arriving in Colorado. Denver, Colorado, Author. Retrieved from https://www.colorado.gov/pacific/sites/default/files/DC_refugee_tbldemographic.pdf

Dixson, A. D., \& Rousseau, C. K. (Eds.). (2006). Critical race theory in education: All God's children got a song. New York, NY: Routledge.

Dooley, K. (2009) Language and inclusion in mainstream classrooms. In J. Miller, A. Kostogriz \& M. Gearon (Eds.), Culturally and linguistically diverse classrooms: New dilemmas for teachers (pp. 75-91). Bristol, U.K: Multilingual Matters.

Dooley, K. T., \& Thangaperumal, P. (2011). Pedagogy and participation: literacy education for low-literate refugee students of African origin in a western school system. Language and Education, 25(5), 385-397. 
Erikson, E. H. (1968). Identity: Youth and crisis. New York, NY: W.W. Norton.

Erikson, E. H. (1972). Childhood and society. London, UK: Vintage.

Fernandéz-Kelly, P., \& Curran, S. (2001). Nicaraguans: Voices lost, voices found. In R. Rumbaut \& A. Portes (Eds.), Ethnicities: Children of immigrants in America (pp. 127-155). Berkeley, CA: University of California Press.

French, D. C., \& Conrad, J. (2001). School dropout as predicted by peer rejection and antisocial behavior. Journal of Research on Adolescence, 11, 225-244.

Galindo, R. (2011). The nativistic legacy of the Americanization era in the education of Mexican immigrant students. Educational Studies, 47(4), 323-346. doi:10.1080/00131946.2011.589308

Gitlin, A., Buendía, E., Crosland, K., \& Doumbia, F. (2003). The production of margin and center: Welcoming-unwelcoming of immigrant students. American Educational Research Journal, 40(1), 91-122.

Glaser, B. G., \& Strauss, A. L. (1967). The discovery of grounded theory: Strategies for qualitative research. Chicago, IL: Aldine.

Harris, A. (2011). Neir Riel (Strong Girls) transgression and fugitive spaces in Sudanese Australian classrooms. Qualitative Inquiry, 17(8), 750-759.

Hatoss, A., O’Neill, S., \& Eacersall, D. (2012). Career choices: Linguistic and educational socialization of Sudanese-background high-school students in Australia. Linguistics and Education, 23(1), 16-30.

Hones, D. F., \& Cha, C. S. (1999). Educating new Americans: Immigrant lives and learning. Mahwah, NJ: Erlbaum.

House, J. D. (2001). The relationship between academic self-concept and school withdrawal. Journal of Social Psychology, 133, 125-127.

Huntsinger, C. S., \& Jose, P. E. (2009). Parental involvement in children's schooling: Different meanings in different cultures. Early Childhood Research Quarterly, 24(4), 398-410.

Hurley, J. J., Warren, R. A., Habalow, R. D., Weber, L. E., \& Tousignant, S. R. (2014). Early childhood special education in a refugee resettlement community: challenges and innovative practices. Early Child Development and Care, 184(1), 50-62.

Kanu, Y. (2008). Educational needs and barriers for African refugee students in Manitoba. Canadian Journal of Education, 31(4), 915-940.

Khan, S., \& VanWynsberghe, R. (2008, January). Cultivating the under-mined: Cross-case analysis as knowledge mobilization. Forum: Qualitative Social Research, 9(1), Retrieved by http://www.qualitative-research.net/index.php/fqs/article/view/334/729

Kirova, A., (2001). Loneliness in immigrant children: Implications for classroom practice. Childhood Education, 77, 260-267.

Kozol, J. (2008). Our education apartheid. Race, Poverty \& the Environment, 15(1), 67-69.

Ladson-Billings, G., \& Tate, W. F. (1995). Toward a critical race theory of education. Teachers College Record, 97(1), 47-68.

Lester, J. N., \& Anders, A. D. (2014). Complicating translation: Children with refugee status and special education testing. NYS TESOL Journal 1(2), 25-38.

Lipman, P. (2013). The new political economy of urban education: Neoliberalism, race, and the right to the city. New York, NY: Taylor \& Francis.

Loomba, A. (2005) Colonialism/postcolonialism. London, UK: Routledge.

Love, B. J. (2004). Brown plus 50 counter-storytelling: A critical race theory analysis of the "majoritarian achievement gap" story. Equity \& Excellence in Education, 37(3), 227-246. 
MacNevin, J. (2012). Learning the way: Teaching and learning with and for youth from refugee backgrounds on Prince Edward Island. Canadian Journal of Education/Revue Canadienne de l'Education, 35(3), 48-63.

Matsuda, M. J., Lawrence, C. R., Delgado, R., \& Crenshaw, K. W. (1993). Words that wound. Boulder, CO: Westview Press.

McBrien, J. L. (2005). Educational needs and barriers for refugee students in the United States: A review of the literature. Review of Educational Research, 75(3), 329-364.

McMurtrie, B., Bollag, B., Brender, A., del Castillo, D., Cheng, M., \& Overland, M. A. (2001). Arab students in U.S. head home, citing growing hostility. Chronicle of Higher Education, 48(6), A42-A45.

Miles, M. B., Huberman, A. M., \& Saldaña, J. (2014). Qualitative data analysis: A methods sourcebook (3rd ed.). Thousand Oaks, CA: Sage.

Mitchell, K. (2012). English is not ALL that matters in the education of secondary multilingual learners and their teachers. International Journal of Multicultural Education, 14(1), 495.

Montgomery, E. (2011). Trauma, exile and mental health in young refugees. Acta Psychiatrica Scandinavica, 124(s440), 1-46.

Mosselson, J. (2007). Masks of achievement: An experiential study of Bosnian female refugees in New York City schools. Comparative Education Review, 51(1), 95-115.

Office of the Adminstration for Children \& Families, (2016). Office of Refugee Resettlement. Washington, DC: U.S. Department of Health \& Human Services. Retrieved from http://www.acf.hhs.gov/programs/orr/programs/wilson-fish/about

Oropeza, M. V., Varghese, M. M., \& Kanno, Y. (2010). Linguistic minority students in higher education: Using, resisting, and negotiating multiple labels. Equity \& Excellence in Education, 43(2), 216-231.

Pérez, L. (2001). Growing up in Cuban Miami: Immigration, the enclave, and new generations. In R. G. Rumbaut \& A. Portes (Eds.), Ethnicities: Children of immigrants in America (pp. 91125). Berkeley, CA: University of California Press.

Portes, A., \& Rumbaut, R. G. (2001). Legacies: The story of the immigrant second generation. Berkeley, CA: University of California Press.

Ragin, C. (1997). Turning the tables: How case-oriented research challenges variable oriented research. Comparative Social Research, 16, 27-42.

Rizvi, F., Lingard, B., \& Lavia, J. (2006). Postcolonialism and education: Negotiating a contested terrain. Pedagogy, Culture \& Society, 14(3), 249-262.

Roxas, K. (2010). Who really wants "the poor, the tired, and the huddled masses" anyway? Teachers' use of cultural scripts with refugee students in public school classrooms. Multicultural Perspective, 12(2), 1-9.

Roy, L., \& Roxas, K. (2011). Whose deficit is this anyhow?: Exploring counter-stories of Somali Bantu refugees' experience in "doing school." Harvard Educational Review, 81(3), 521541.

Roxas, K., \& Roy, L. (2012). Learning from Somali Bantu refugee students: Recommendations for teachers in the field. Teacher Education and Practice, 25(1), 100-118.

Said, E. (1978). Orientalism. London, UK: Penguin.

Said, E. (1993). Culture and Imperialism. London, UK: Chatto and Windus.

Saldaña, J. (2013). The coding manual for qualitative researchers. Thousand Oaks, CA: Sage. 
Sinclair, M. (2001). Education in emergencies. In J. Crisp, C. Talbot, \& D. B. Cipollone (Eds.), Learning for a future: Refugee education in developing countries (pp. 1-84). Lausanne, Switzerland: United Nations Publications.

South, A. (2011). Burma's longest war: Anatomy of the Karen conflict. Amsterdam, Netherlands: Transnational Institute. Retrieved from https://www.tni.org/en/briefing/burmas-longestwar-anatomy-karen-conflict

Stake, R. E. (2006). Multiple case study analysis. New York, NY: Guilford Press.

Stepick, A., Stepick, C. D., Eugene, E., Teed, D., \& Labissiere, Y. (2001). Shifting identities and intergenerational conflict: Growing up Haitian in Miami. In R. G. Rumbaut \& A. Portes (Eds.), Ethnicities: Children of immigrants in America (pp. 229-266). Berkeley, CA: University of California Press.

Subedi, B., \& Daza, S. L. (2008). The possibilities of postcolonial praxis in education. Race Ethnicity and Education, 11(1), 1-10.

Thorstensson Dávila, L. (2014). Representing refugee youth in qualitative research: Questions of ethics, language and authenticity. Diaspora, Indigenous, and Minority Education, 8(1), 2131.

Tollefson, J. (1989). Alien winds: The reeducation of America's Indochinese refugees. New York, NY: Praeger.

Trickett, E. J., \& Birman, D. (2005). Acculturation, school context, and school outcomes: Adaptation of refugee adolescents from the former Soviet Union. Psychology in the Schools, 42(1), 27-38.

Trieu, M. M., \& Vang, C. Y. (2015). A Portrait of Refugees from Burma/Myanmar and Bhutan in the United States. Journal of Asian American Studies, 18(3), 347-369.

Uptin, J., Wright, J., \& Harwood, V. (2014). Finding education: Stories of how young former refugees constituted strategic identities in order to access school. Race Ethnicity and Education, 18(4), 1-20.

Viesca, K. M., Matias, C., Garrison-Wade, D., Galindo, R., \& Tandon, M. (2014). "Push it real good!": The challenge of disrupting dominant discourses regarding race in teacher education. Critical Education, 5(11).

Wallitt, R. (2008). Cambodian invisibility: Students lost between the "achievement gap" and the "model minority." Multicultural Perspectives, 10(1), 3-9.

WIDA. (2014). Can-do descriptors. Madison, WI: University of Wisconsin. Retrieved from http://www.wida.us/standards/CAN_DOs/

Wingfield, M., \& Karaman, B. (2001). Arab stereotypes and American educators. Retrieved from http://www.adc. org/index.php?id=246

Yin, R. K. (2003). Case study research: Design and methods (3rd ed.). Beverly Hills, CA: Sage.

Yosso, T. J. (2005). Whose culture has capital? A critical race theory discussion of community cultural wealth. Race Ethnicity and Education, 8(1), 69-91.

Yosso, T. J. (2006). Critical race counterstories along the Chicana/Chicano educational pipeline. New York, NY: Routledge.

Yosso, T. J., \& Solórzano, D. (2005). Conceptualizing a critical race theory in sociology. In M. Romero \& E. Margolis (Eds.), The Blackwell companion to social inequalities, (pp. 117146) Malden, MA: Blackwell. 


\section{APPENDIX A}

Semi-structured Interview Protocol

Demographic Data

\begin{tabular}{l}
\hline Participant \\
Age \\
Gender \\
Religion \\
Country of birth \\
Country (or Countries) of displacement prior to the \\
United States \\
Number of years spent in school prior to the United \\
States \\
Type of schooling prior to the United States \\
(homeschooling, public, private, parochial, etc.) \\
Languages spoken \\
Language(s) of instruction prior to the United States \\
Number of older siblings (if any) \\
Number of younger siblings (if any)
\end{tabular}

\section{Part I) Background information relating to educational experiences of adolescent refugee students prior to being resettled in the United States?}

Question 1) Can you tell me about your school in (country of origin)?

Probes: What was your elementary school like? Middle School? What languages were used in your school? What was the teaching like? What was the study body like? Did you go to school every day? What were the teachers like? etc.

Question 2) Can you tell me about your school in (first country of refuge)?

Probes: What was your elementary school like? Middle School? What languages were used in your school? What was the teaching like? What was the study body like? Did you go to school every day? What were the teachers like? Did you take any exams? etc.

Question 3) Can you tell me about your school in (second country of refuge or refugee camp)?

Probes: What was your elementary school like? Middle School? What languages were used in your school? What was the teaching like? What was the study body like? Did you go to school every day? What were the teachers like? etc.

Question 4) What grade were you in before you came to the United States?

Question 5) What was the language of instruction in each school?

Part II) How do adolescent refugee students conceptualize schooling, education, and success and how do they plan to achieve their career goals?

Question 6) Do you think school and education is important? Why/Why not?

Probes: What do you think of your English Language (EL) classes? Do you need them? Do you spend too much/too little time in them? How helpful are they? If you did not have to attend EL classes what other courses would you take? How will you learn if you are not fluent in EL? etc. 
Question 7) What subjects are you most interested in? What is your favorite class at school?

Question 8) If you did not have to be at school what would you be doing? What would you like to be doing? Do you like coming to this school? Why/Why not?

Question 9) Have you thought about your plans after high school? If so, tell me more.

Question 10) Most immigrants come to the United States of America with a dream. Do you have one? If so what is it?

Question 11) What does success mean to you? What does it look like?

Question 12) Do you think you will be successful? How will you do it?

Question 13) Do you think that your school experience would have been different if you were White/Male/native English speaker? etc.

\section{Part III) Which factors influence their decisions about careers?}

Question 13) If you do not attend school what will your family say/think?

Question14) What does your family say about education? What would they like you to become?

Question 15) What are some of the biggest obstacles in your path to success?

Question 16) What will you tell your friends back home about coming to the U.S.?

Question 17) What can schools and teachers do to help you achieve your dream?

Question 18) Do you think your school would have treated you differently if you were White/Male/native English speaker? etc.

Question 19) What can parents and communities do to help you achieve your dream? 


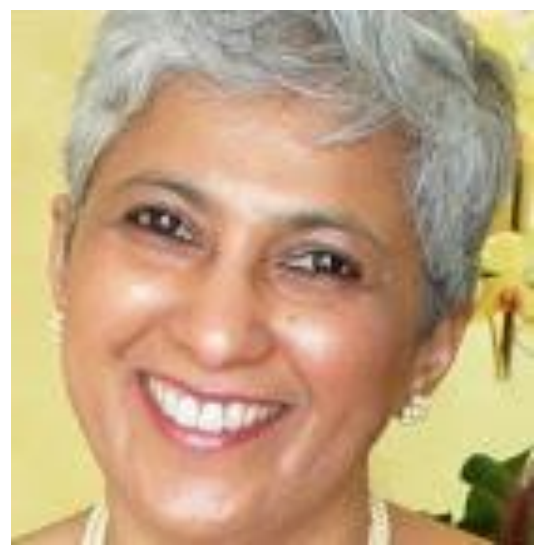

Dr. Madhavi Tandon started her teaching journey in an $8^{\text {th }}$ grade classroom in Pune, India and since then she has taught in schools, colleges and universities in Europe and the United States for the last several decades. Dr. Tandon has extensive experience in shaping education policy with a focus on redressing inequities and marginalization and works with several schools internationally to improve curriculum and classroom practices. Dr. Tandon currently heads Symbiosis Schools in India and also teaches at Symbiosis International University. 


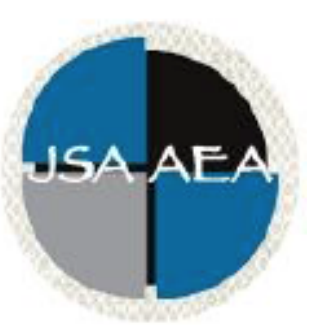

Journal of Southeast Asian American

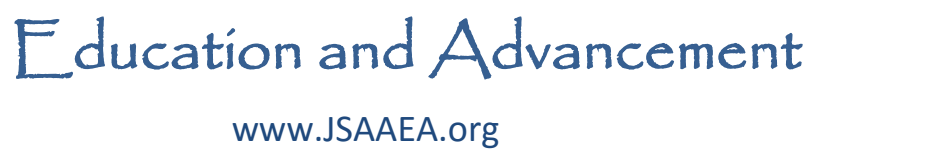

\author{
Editor \\ Dr. Wayne E. Wright \\ Purdue University \\ Associate Editors \\ Dr. Chhany Sak-Humphry \\ University of Hawaii at Manoa \\ Dr. Phitsamay Sychitkokhong Uy \\ University of Massachusetts, Lowell \\ Book Review Editor \\ Dr. Vichet Chhuon \\ University of Minnesota \\ Creative Works Editor \\ Bryan Thao Worra \\ Lao Assistance Center \\ Journal Manager \\ Sung Ae Kim \\ Purdue University
}

\title{
Editorial Review Board
}

Dr. Steve Arounsack

California State University, Stanislaus

Dr. Sovicheth Boun

The State University of New York at

Fredonia

Dr. George Chigas

University of Massachusetts, Lowell

Dr. Hien Duc Do

San Jose State University

Dr. Sophal Ear

Occidental College
Dr. Carl L. Bankston III

Tulane University

Dr. Phala Chea

Lowell Public Schools

Dr. Loan Dao

University of Massachusetts, Boston

Dr. Changming Duan

University of Missouri, Kansas City

Dr. Sothy Eng

Lehigh University 


\author{
Dr. Nancy H. Hornberer \\ University of Pennsylvania \\ Dr. Zha Blong Xiong \\ University of Minnesota \\ Dr. Peter Nien-Chu Kiang \\ University of Massachusetts, Boston \\ Dr. Ha Lam \\ Eastern Mennonite University \\ Dr. Jonathan H. X. Lee \\ San Francisco State University \\ Dr. Monirith Ly \\ Royal University of Phnom Penh \\ Dr. Bic Ngo \\ University of Minnesota \\ Dr. Leakhena Nou \\ California State University, Long Beach \\ Dr. Mark Pfeifer \\ SUNY Institute of Technology \\ Dr. Loan T. Phan \\ University of New Hampshire \\ Dr. Kalyani Rai \\ University of Wisconsin, Milwaukee \\ Dr. Cathy J. Schlund-Vials \\ University of Connecticut, Storrs \\ Dr. Nancy J. Smith-Hefner \\ Boston University \\ Dr. Yer J. Thao \\ Portland State University \\ Dr. Monica M. Trieu \\ Purdue University \\ Dr. Silvy Un \\ Saint Paul Public Schools \\ Dr. Terrence G. Wiley \\ Center for Applied Linguistics
}

\author{
Dr. Vincent K. Her \\ University of Wisconsin, Eau Claire
}

Dr. Peter Tan Keo

New York University

Dr. Kevin K. Kumashiro

University of San Francisco

Dr. Ravy Lao

California State University, Los Angeles

Dr. Stacey Lee

University of Wisconsin, Madison

Dr. Sue Needham

California State University, Dominguez Hills

Dr. Max Niedzwiecki

Daylight Consulting Group

Dr. Clara Park

California State University, Northridge

Dr. Giang Pham

University of Massachusetts

Dr. Karen Quintiliani

California State University, Long Beach

Dr. Angela Reyes

Hunter College, City University of New York

Dr. Fay Shin

California State University, Long Beach

Dr. Christine Su

Ohio University

Dr. Alisia Tran

Arizona State University

Dr. Khatharya Um

University of California, Berkeley

Dr. Linda Trinh Vo

University of California, Irvine

Dr. Yang Sao Xiong

University of Wisconsin-Madison

\section{Doctoral Student Editorial Review Board}

Virak Chan

University of Texas at San Antonio
Keo Chea-Young

University of Pennsylvania 
Annie BichLoan Duong

San Joaquin County Office of Education

Hoa Nha Nguyen

Boston College

Malaphone Phommasa

Marshall University

Molly Wiebie

The University of Texas at Austin

Anna H. Yang

University of Georgia
Dung Minh Mao

University of Minnesota

Thien-Huong Ninh

University of Southern California

Krissyvan Truong

Claremont Graduate University

Soua Xiong

San Diego State University \&

Claremont Graduate University

\author{
Linh Dang \\ University of Rochester
}

